\title{
PELAYANAN INFORMASI PUBLIK PADA DINAS KOMUNIKASI DAN INFORMASI KABUPATEN DONGGALA
}

\author{
Ade Irma \\ Program Studi Ilmu Administrasi Publik Sekolah Tinggi \\ Ilmu Administrasi Pembangunan Palu \\ *Email: Adeirmaoke6@gmail.com
}

\begin{abstract}
Pillars of democracy, transparency and good governance are the objectives of public information services carried out, through Law No. 14 of 2008 on Public Information Disclosure. The form of service organized by the Government is a service in an effort to meet the needs of the public or the community. Communication, Public information is information generated, stored, managed, sent, and / or received by a public body, this research is a qualitative approach, a research paradigm to describe events, locus research located in the Department of Communication and Informatics Donggala Regency, this study uses Informants as many as 4 (four) people, using the theory of Pararusman, et al .Tjiptnono, 1996) there are five dimensions in assessing the quality of services or services, namely, Tangibles, Realibility, Responsiveness, Assurance, Emphathy. 1) Tangibles; reflected in physical facilities, equipment, personnel and communication materials have not been effective and optimal.2) Realibility, i.e. lack of accuracy or lack of reliable information. Responsiveness: lack of sensitivity to respond to information. 4) Assurance; Knowledge is less effective and efficient. 5) Emphathy. Still lacking, officers in the process of public information services
\end{abstract}

Keywords: Tangibles; Realibility; Responsiveness; Assurance; Emphathy

\begin{abstract}
ABSTRAK
Pilar demokrasi, transparansi dan good governance adalah tujuan dari pelayanan informasi publik yang dilakukan, melalui Undang-Undang Nomor 14 Tahun 2008 tentang Keterbukaan Informasi Publik. Bentuk pelayanan yang diselenggarakan oleh Pemerintah merupakan pelayanan dalam upaya memenuhi kebutuhan publik atau masyarakat. Komunikasi, Informasi publik adalah informasi yang dihasilkan, disimpan, dikelola, dikirim, dan/atau diterima oleh suatu badan publik, penelitian ini adalah pendekatan kualitatif, suatu paradigma penelitian untuk menggambarkan peristiwa, Lokus penelitian bertempat di Dinas Komunikasi dan Informatika Kabupaten Donggala, penelitian ini menggunakan Informan sebanyak 4 (empat) orang, dengan menggunakan teori Pararusman, dkk (Tjiptnono, 1996) ada lima dimensi dalam menilai kualitas jasa atau pelayanan, 1) Tangibles; tercermin pada fasilitas fisik, peralatan,personil dan bahan komunikasi belum efektif dan optimal.2) Realibility,yaitu kurang akurat atau kurangnya terpercaya informasi peleyanan. 3) Responsiveness; yaitu kurangnya kepekaan merespon informasi. 4) Assurance; pengetahuan masih kurang efektif dan efisien. 5) Emphathy. Masih kurang, petugas dalam proses pelayanan informasi publik
\end{abstract}

Kata Kunci: Kemampuan; Kepuasan; Ketanggapan; Jaminan; Empati Submisi: 28 Desember 2021

\section{Pendahuluan}

Tujuan utama dibentuknya pemerintahan adalah untuk menjaga suatu sistem ketertiban dimana masyarakat bisa menjalani kehidupan secara wajar. Pemerintahan modern pada hakekatnya adalah memberikan pelayanan kepada masyarakat atau biasa disebut pelayanan publik (public service). Pelayanan Publik sendiri merupakan kegiatan-kegiatan dan objek-objek tertentu yang secara khusus dimaksudkan untuk memenuhi kebutuhan 
masyarakat umum (the general publik) atau memberikan dukungan terhadap upaya meningkatkan kenikmatan dan kemudahan (comfort and convenience) bagi seluruh masyarakat.(Puluadji, Pakaya, and Djafar 2016).

Dinas Komunikasi dan Informatika Kabupaten Donggala merupakan badan publik yang bertugas untuk menyediakan informasi dan melakukan pelayanan informatika dalam menjalankan tugas dan fungsinya. Keterbukaan informasi publik merupakan salah satu pilar kebebasan berekspresi serta pilar demokrasi, transparansi dan good governance. Tuntutan ini mendorong hadirnya Undang-Undang Nomor 14 Tahun 2008 tentang Keterbukaan Informasi Publik (UU KIP). Dalam undangundang, tersebut, hak masyarakat untuk mendapatkan informasi mendapatkan jaminan, dan implementasi kebijakan keterbukaan informasi publik menjadi salah satu upaya pemenuhan hak asasi manusia (HAM).

Berlakunya UU KIP tersebut secara subtansial melekat pada kedua belah pihak, yaitu: penyelenggara badan publik dan masyarakat luas. Pada pihak penyelenggara badan publik mempunyai kewajiban untuk menunjuk Pejabat Pengelola Infomasi dan Dokumentasi (PPID) serta mengklarifikasikan informasi yang wajib disediakan dan diumumkan secara berkala, informasi yang wajib di umumkan serta merta, dan informasi yang wajib disediakan jika ada permohonan informasi dari masyarakat.(Herlina 2020).

Revolusi industri 4.0 tidak saja berpengaruh pada sektor industri, tetapi juga berdampak pada sektor pelayanan publik dan atau atau birokrasi. Data World Economy Forum Human Capital Indonesia pada tahun 2017 menyebutkan bahwa kualitas Aparatur Sipil Negara (ASN) Indonesia lebih rendah dibandingkan Malaysia dan Thailand (Masrully, 2019). Peraturan terkait pengembangan kompetensi ASN sudah ada. Kementerian Pendayagunaan Aparatur Negara dan Reformasi Birokrasi (KemenPAN-RB) telah menyusun grand design pembangunan ASN 2020-2024 untuk mewujudkan tata kelola pemerintahan yang profesional, berdasar hukum, serta kompeten dalam menghadapi IR 4.0 (Humas Kemenpan RB, 2018). Sementara itu, Peraturan Kepala Lembaga Administrasi Negara (LAN) Nomor 10 tahun 2018 tentang Pengembangan Kompetensi Pegawai Negeri Sipil (2018) mengamanatkan skema pertukaran PNS dengan pegawai swasta atau badan usaha milik negara atau daerah untuk meningkatkan kompetensi bidang teknis. Dengan demikian, ASN sangat dimungkinkan untuk belajar teknologi IR 4.0 dengan pihak swasta. Hal ini mengindikasikan keseriusan pemerintah untuk memiliki SDM yang melek teknologi.(Komunikasi 2020).

Komunikasi merupakan hal yang mudah, namun terkadang sulit dilaksanakan, namun demikian pada tataran komunikasi secara keseluruhan, baik proses penyampaian pesan maupun penafsiran masing-masing individu akan memberikan dampak atau pengaruh. Melalui komunikasi yang baik akan selalu berhasil dalam mencapai tujuan yang diinginkan jika komunikasi yang dilakukan dilaksanakan dengan komunikasi yang efektif. Melalui komunikasi yang efektif inilah proses komunikasi dapat berjalan dengan lancar, sehingga yang ada dalam diri seorang komunikator akan tersampaikan dengan makna yang sama dengan komunikator lain yang terlibat dalam proses komunikasi, tidak terkecuali dalam penyelesaian suatu konflik atau perselisihan yang selalu bersinggungan langsung dengan banyak orang.(Rahmat 2021).

Dalam kontek good governance, pelayanan publik merupakan gerbang utama reformasi birokrasi pemerintah, karena di dalam pelayanan publik merupakan ruang dimana birokrasi pemerintahan berinteraksi secara langsung dengan masyarakat. Di era New Public Service inilah pelayanan publik harus lebih responsif karena akan langsung terpantau secara transparan oleh masyarakat.(Hidayah 2020). 
Kemajuan teknologi informasi sebagai bagian dari globalisasi tidak terpisahkan dari masyarakat modern seperti sekarang ini yang telah membawa tuntutan yang besar bagi masyarakat terhadap pemerintah sebagai penyedia layanan untuk lebih bersifat terbuka, lebih efektif dan efisien dalam melaksanakan tugas kepemerintahannya, dan juga memberikan kemudahan terhadap akses informasi khususnya informasi tentang pemerintahan. Sehingga mendorong pemerintah untuk melaksanakan sebuah konsep tata kepemerintahan baik yang lazim disebut dengan good governance. Kaitannya dalam perwujudan pelayanan publik yang good governance, pemerintah dituntut untuk beradaptasi dengan perkembangan teknologi agar tidak tertinggal. Hage dan Powers (Anwar), menyebutkan salah satu ciri yang menonjol di era kemajuan teknologi komunikasi dan informasi ini adalah digunakannya teknologi komputer. E-government merupakan penggunaan dan pemanfaatan teknologi informasi oleh pemerintah agar tercipta komunikasi antara pemerintah, masyarakat, dunia bisnis dan pihak-pihak lain yang berkepentingan untuk memberikan pelayanan secara cepat dan tepat.(Dan and Di n.d.).

Berdasarkan atas hal tersebut diatas maka peneliti menemukan share problems yaitu bagaimanakah pelayanan informasi publik pada Dinas Komunikasi dan Informasi Kabupaten Donggala.

\section{Pelayanan}

Pelayanan publik adalah kegiatan atau rangkaian kegiatan dalam rangkapemenuhan kebutuhan pelayanan sesuai dengan peraturan perundangundanganbagi setiap warga negara dan penduduk atas barang, jasa dan/atau pelayanan administratif yang disediakan oleh penyelenggarapelayanan publik. Pelayanan publik merupakan suatu usaha yang dilakukan kelompok atauseseorang birokrasi untuk memberikan bantuan kepada masyarakat dalamrangka mencapai suatu tujuan tertentu.(Selviana A.
Wahid and Dirja N. Jahya 2018). Bentuk pelayanan yang diselenggarakan oleh Pemerintah merupakan pelayanan dalam upaya memenuhi kebutuhan publik atau masyarakat, sehingga disebut dengan pelayanan publik. Pelayanan publik umumnya dilakukan oleh Pemeirntah untuk memenuhi berbagai kebutuhan masyarakatnya. Pemerintah bertanggung jawab atas penyelenggaraan dalam memberikan pelayanan baik di lingkungan Pemerintaha Pusat, Pemerintahan Daerah, Badan-Badan Umum milik Pemerintah dalam rangka pelaksanaan ketentuan peraturan perundang-undangan yang berlaku. Setiap pelayanan yang diberikan oleh Pemerintah harus dapat memuaskan publik atau masyarakat, ketika banyak kebijakan yang dibuat telah diundangkan oleh pemerintah, maka menjadi kewajiban pemerintah untuk memberikan pelayanan prima kepada publik atau masyarakat. Pelayanan yang berkualitas juga harus berpegang kepada prinsip- prinisp pelayanan, diantaranya adanyanya transparansi, mudah di akses, memiliki ketepatan dan keakuratan, pelayanan yang dapat dipertanggung jawabkan, tidak adanya diskriminasi dalam pelayanan, memberikan hak yang sama antara pemberi dan penerima layanan.(Rosmajudi 2020).

Menurut Kurniawan (dalam Sinambela : 2006 : 5) pelayanan publik diartikan sebagai pemberi pelayanan (melayani) keperluan orang atau masyarakat yang mempunyai kepentingan pada organisasi itu sesuai dengan aturan pokok dan tata cara yang ditetapkan. Pengertian pelayanan umum menurut Keputusan Menteri Negara Pendayagunaan Aparatur Negara (Men-PAN) Nomor 81 Tahun 1993 adakah segala bentuk kegiatan pelayanan umum yang dilaksanakan oleh instansi pemerintah pusat, di daerah, dan lingkungan Badan Usaha Milik Negara / Daerah dalam bentuk barang dan jasa, baik dalam rangka upaya pemenuhan kebutuhan masyarakat maupun dalam rangka upaya pemenuhan kebutuhan masyarakat maupun dalam 
rangka pelaksanaan ketentuan peraturan perundang - undangan. Sedangkan kulitas pelayanan publik dapat diukur dengan tiga dimensi menurut Lenvinne dalam Hardiyansyah (2011:53) yaitu : Responsiveness atau responsivitas ini mengukur daya tanggap providers terhadap harapan, keinginan dan aspirasi serta tuntutan customers. Responsibility atau responsibilitas adalah suatu ukuran yang menunjukkan seberapa jauh proses pemberian pelayanan publik itu dilakukan dengan tidak melanggar ketentuanketentuan yang telah ditetapkan. Accountability atau akuntabilitas adalah suatu ukuran yang menunjukkan seberapa besar tingkat kesesuaian antara penyelengaraan pelayanan dengan ukuran-ukuran eksternal yang ada di masyarakat dan dimiliki oleh stakeholders, seperti nilai dan norma yang berkembang dalam masyarakat.(Dan and Di n.d.).

Setiap pelayanan yang diberikan oleh Pemerintah harus dapat memuaskan publik atau masyarakat, ketika banyak kebijakan yang dibuat telah diundangkan oleh pemerintah, maka menjadi kewajiban pemerintah untuk memberikan pelayanan prima kepada publik atau masyarakat. Pelayanan yang berkualitas juga harus berpegang kepada prinsip- prinisp pelayanan, diantaranya adanyanya transparansi, mudah di akses, memiliki ketepatan dan keakuratan, pelayanan yang dapat dipertanggungjawabkan, tidak adanya diskriminasi dalam pelayanan, memberikan hak yang sama antara pemberi dan penerima layanan.(Rosmajudi 2020).

(Ananda, Putera, and Ariany 2020), Untuk mencapai good governance dengan kepuasan masyarakat terhadap pelayanan yang diberikan, Depertemen Kesehatan Indonesia juga menekankan pada pentingnya kualitas pelayanan kesehatan yang lebih baik, karena mengingat rumah sakit sebagai salah satu saran penyedia layanan kesehatan yang sudah menjadi kebutuhan pokok masyarakat sebagai fasilitas mutlak yang harus ada dan mencukupi kebutuhan masyarakat baik dari kuantitas maupun kulitas pelayanan yang diberikan. Dengan semakin meningkatnya demand masyarakat akan kualitas pelayanan kesehatan maka pelayanan kesehatanyang diberikan rumah sakit harus ditingkatkan agar lebih efektif dan efisien dengan tetap memperhatikan mutu, prinsip serta kelayakan dan etika pelayanan kesehatan, sebab kualitas pelayanan merupakan suatu bentuk penilaian konsumen (pasien) terhadap tingkat pelayanan yang diterima dengan tingkat layanan yang diharapkan (Azrul. 1996).

Pelayanan publik adalah pemenuhan keinginan dan kebutuhan masyarakat oleh penyelenggara negara. Negara didirikan oleh publik (masyarakat) tentu saja dengan tujuan agar dapat meningkatkan kesejahteraan masyarakat. Pada hakikatnya, negara dalam hal ini pemerintah (birokrat) haruslah dapat memenuhi kebutuhan masyarakat. Kebutuhan dalam hal ini bukanlah kebutuhan secara individual, tetapi berbagai kebutuhan yang sesungguhnya diharapkan oleh masyarakat misalnya kebutuhan pendidikan, kesehatan, dan jasa umum lainnya.(Jaya 2019).

\section{Komunikasi}

Rakhmat (Awanis \& Adiyanti, 2020: 136) menjelaskan bahwa komunikasi dapat efektif apabila penerima pesan menginterpretasikan pesan yang diterimanya seperti yang dimaksudkan pengirimnya. Collin Cherry (1964) dalam (Permadi, 2018: 525) mendefinisikan komunikasi sebagai "usaha untuk membuat satuan sosial dari individu dengan menggunakan bahasa atau tanda. Psikologi mengarahkan perhatiannya pada perilaku manusia mencoba menyimpulkan proses kesadaran yang menyebabkan terjadinya perilaku tersebut. Komunikasi yang membahas tentang persepsi tentunya juga akan mengkaji dalam hal psikologi. Pada dasarnya bahwa menurut Fisher (Permadi, 2018) psikologi melihat pada perilaku individu komunikan. Fisher menyebut empat ciri psikologi pada komunikasi, yaitu: (1) Penerimaan stimuli secara indrawi, (2) 
Proses yang mengantarai stimuli dan respon, (3) Prediksi respon dan (4) Peneguhan respon.(Siahaan et al. 2021).

Tubb dan Moss (2006) terdapat lima faktor instrumen komunikasi berjalan dengan efektif yaitu (1) pemahaman terhadap pesan oleh penerima, (2) memberikan kesenangan kepada pihakpihak yang berkomunikasi, memengaruhi sikap orang lain, (4) memperbaiki hubungan, (5) memberikan hasil yang sesuai dengan yang diinginkan dalam bentuk tindakan dari penerima pesan.(Kusumadinata and Fitriah 2017).

\section{Informasi Publik}

Informasi publik adalah informasi yang dihasilkan, disimpan, dikelola, dikirim, dan/atau diterima oleh suatu badan publik yang berkaitan dengan penyelenggara dan penyelenggaraan negara dan/atau penyelenggara dan penyelenggaraan badan publik lainnya yang sesuai dengan Undang Undang Komisi Informasi Publik serta informasi lain yang berkaitan dengan kepentingan publik (Pasal 1:2 Undang Undang Komisi Informasi Publik). Semua informasi publik bersifat terbuka, kecuali yang dinyatakan dikecualikan, sesuai dengan Pasal 17 Undang Undang Komisi Informasi Publik. Adapun informasi yang dikecualikan itu adalah: a)Informasi yang dapat menghambat proses penegakan hukum. b)Informasi yang dapat menganggu kepentingan perlindungan hak atas kekayaan intelektual dan perlindungan dari persaingan tidak sehat. c)Informasi yang dapat membahayakan pertahanan dan keamanan negara. d)Informasi yang dapat mengungkapkan kekayaan alam Indonesia. e)Informasi dapat merugikan ketahanan ekonomi nasional. f)Informasi yang dapat merugikan kepentingan hubungan luar negeri. g) Informasi yang mengungkapkan isi akta otentik yang bersifat pribadi dan kemauan terakhir atau wasiat seseorang. f)Informasi yang dapat mengungkapkan rahasia pribadi. Pergeseran penyebab terjadinya sengketa informasi publik itu menunjukkan bahwa telah terjadi perkembangan pemahaman di badan publik mengenai hak masyarakat atas informasi publik. Dari awalnya tidak memenuhi kewajiban membuka informasi yang seharusnya terbuka, badan publik kemudian mulai memenuhi kewajiban ini. Perkembangan juga menunjukkan bahwa pada awal-awal tahun diberlakukannya Undang-Undang ini, badan publik pemerintah acapkali menggunakan alasan dalam mengecualikan informasi berdasar alasan kerahasiaan negara. Namun alasan itu kemudaian bergeser, seiring dengan pengalaman bersidang di Komisi Informasi, kebanyakan badan publik tidak lagi menyatakan menutup status suatu informasi karena merupakan rahasia negara, namun menggunakan berbagai alasan lain. Alasan yang lebih sering digunakan oleh Badan Publik Pemerintah untuk menyatakan sebuah informasi dikecualikan, yaitu : (1) alasan jika informasi dibuka akan menyebabkan terungkapnya rahasia pribadi seseorang; dan (2) alasan jika informasi dibuka akan menyebabkan terjadinya persaingan usaha tidak sehat dan/atau alasan lain yang diatur dalam pasal 17 Undang Undang Komisi Informasi Publik.(Paribrata 2017).

\section{Konseptualisasi Penelitian}

Pendekatan yang digunakan dalam penelitian ini adalah pendekatan kualitatif, suatu paradigma penelitian untuk menggambarkan peristiwa, perilaku orang atau suatu situasi pada suatu tempat tertentu secara rinci dan mendalam dalam bentuk narasi dengan maksud atau tujuan untuk mengetahui informasi tentang Pelayanan Informasi Publik Yang selama ini dinilai masih terdapat banyak kekurangankekurangan dan Mis-Kom di masyarakat pada aspek peleyanan. Penelitian ini dilakukan dengan menggunakan prinsip kualitatif. Berbagai informasi penelitian akan diambil sampai cukup untuk dianalisis berdasarkan prosedur dari prinsip-prinsip metodologi kualitatif. Lokus penelitian bertempat di Dinas Komunikasi dan Informatika Kabupaten Donggala, 
penelitian ini menggunakan Informan dimana informan adalah orang-orang yang dianggap dapat memberikan informasi mengenai objek penelitian sebanyak 4 (empat) orang, yang terdiri dari informan kunci dan informan sekunder. Data yang diolah adalah data kuali yaitu data yang berkaitan dengan kategorisasi, kerateristik yang berwujud pertanyaan atau berupa katakata. Dalam penelitian ini jenis data yang diperoleh adalah data primer dan data sekunder. Dalam penelitian kualitatif yang menjadi instrumen atau alat penelitian adalah peneliti itu sendiri. Teknik pengumpulan data merupakan langkah yang paling strategis dalam penelitian, yaitu dengan observasi dan wawancara. Kemudian data tersebut kemudian dianalisis dengan menggunakan teknik analisis. Michael Huberman, yang meliputi tiga kegiatan bersamaan yaitu 1) Pengumpulan Data Primer dan Sekunder 2) Reduksi Data, 3) Penyajian Data dan 4) Penarikan Kesimpulan (Verifikasi).

\section{Hasil Penelitian dan Pembahasan}

Pararusman, dkk (Tjiptnono, 1996) ada lima dimensi dalam menilai kualitas jasa atau pelayanan, yaitu: 1) Tangibles; tercermin pada fasilitas fisik, peralatan,personil dan bahan komunikasi. 2) Realibility; kemampuan memenuhi pelayanan yang dijanjikan secara terpercaya, tepat 3) Responsiveness; kemamuan untuk membantu pelanggan dan menyediakan pelayanan yang tepat 4) Assurance; pengetahuan dari para pegawai dan kemampuan mereka untuk menerima kepercayaan dan kerahasiaan 5) Emphathy.(Maysaroh 2018). Untuk menguji data pada penelitian Pelayanan Informasi Publik Pada Dinas Komunikasi Dan Informasi Kabupaten Donggala.

Tangibles,fasilitas,fisik, peralatan, personil dan bahan komunikasi dalam hasil penelitian yang dilakukan ditemukan bahwa informan dominan mengatakan dari segi, terdapat banyak masalah dalam berkomunikasi mengingat luas wilayah kabupaten Donggala yang luas sehingga cakupan informasi pelayanan publik terbatas. Dimana memiliki tugas dalam melaksanakan kebijakan penyelenggaraan urusan komunikasi dan informatika, statistik serta persandian. Dalam melaksanakan tugas pokok dan fungsi yang dimilikinya, memerlukan sumberdaya, baik sumber daya manusia atau pegawai yang memiliki kompetensi dibidang pekerjaannya masingmasing, dan tersedianya sarana dan prasarana pendukung dalam mencapai keberhasilan pekerjaan baik untuk inidividu pegawai, maupun tujuan organisasi. Keberhasilan organisasi tidak terlepas dari peran sumberdaya yang dimilikinya, dimana manusia memiliki peran penting dibandingkan sumberdaya lainnya. Secara prinsip penempatan pegawai yang tepat dalam pekerjaan yang tepat sangat diperlukan untuk menciptakan kehandalan dan profesionalisme pegawai. SDM yang berkualitas tidak terlepas dari tingkat pendidikan yang telah ditempuh baik formal maupun non-formal.

Apabila dibandingkan dengan penelitian terdahulu yang diperoleh adalah faktor-faktor yang dapat mempengaruhi keberhasilan implementasi kebijakan yaitu Faktor Komunikasi, Sumber Daya, Disposisi dan Struktur Birokrasi sudah cukup terpenuhi dengan baik, hanya saja terdapat kendala pada faktor sumber daya yaitu kurangnya jumlah staf seksi pelayanan informasi publik yang merupakan implementor dalam kebijakan tersebut, selain itu belum terpenuhinya fasilitas penunjang seperti kamera profesional. Meskipun jumlah staf yang kurang memadai, implementor memiliki keahlian dalam menjalankan kebijakan tersebut yaitu mampu mengoperasikan website dan juga media sosial sebagai sarana menyebarluaskan informasi publik. (Herlina 2020).

Realibility; kemampuan memenuhi pelayanan yang dijanjikan secara terpercaya, tepat, setelah dilakukannya penelitian dengan mewawancarai beberapa informan diketemui kondisi empiris bahwa informasi pelayanan publik yang masih kurang akurat 
yaitu kurang terpercayanya informasi yang diterima disebabkan oleh aparatur atau petugas yang menjalankan pelayanan publik tersebut tidak melaksanakan tugas dan tanggung jawab secara efektif dan efisien dalam pengelolaan pelayanan publik tersebut. Serta kurangnya skill (kemampuan) petugas dalam berkomunikasi pada saat melakukan pelayanan publik dapat memperlambat proses pelayanan publik. Sehingganya banyak terdahap pekerjaan pekerjaan (seperti pelayanan administrasi, pelayanan komunikasi dan informasi) menjadi terganggu atau bermasalah.

Responsiveness; atau kemampuan untuk membantu dan menyediakan pelayanan yang tepat, namun berdasarkan atas penelitian yang telah dilakukan informan memberikan pernyataan bahwa pelayanan sudah sesuai SOP (Standart Operational Procedure), hanya saja petugas masih belum memiliki kepekaan merespon pernmintaan - permintaan masyarakat respon yang kurang ramah, dan sedikit agak lambat, serta motivasi, dalam memberikan pelayanan informasi kepada masyarakat, belum ada inisiatif secara individu, dorongan yang kuat dalam pelayanan, sehingga setiap informasi pelayanan publik menjadi lambat atau kurang uptodate. Keluhan - keluhan yang terkabar dimasyarakat menjadi PR yang harus diselesaikan oleh Pemerintah.

Dibandingan dengan penelitian yang dilakukan oleh (Herlina 2020). Adanya Undang-undang yang mengatur keterbukaan informasi publik mewajibkan seluruh badan publik untuk memenuhi kebutuhan informasi publik masyarakatnya. Sebagai badan publik, pemerintah Kota Tasikmalaya memiliki kewajiban untuk memenuhi kebutuhan informasi publik masyarakat Kota Tasikmalaya sesuai dengan UU KIP No 14/2008 yang dijadikan sebagai pedomannya. Seksi Pelayanan Informasi Publik merupakan seksi yang berada dalam Bidang Informasi, Komunikasi Publik dan Statistik. Dalam implementasi kebijakan keterbukaan informasi publik, petugas pelayanan informasi publik memiliki tanggung jawab untuk melaksanakan dari mulai perencanaan hingga penyebarluasan informasi publik, dan juga layanan hubungan media.

Assurance; kepercayaan dan kerahasiaan setelah dilakukannya wawancara kepada informan, kepercayaan masyarakat terhadap kepada Dinas Komunikasi dan Informasi Kabupaten Donggala masih kurang, disebabkan oleh, kurangnya edukasi atau sosialisasi kepada masyarakat terhadap informasi publik. Sehingga pelayanan tersebut menjadi kurang efektif dan efisien.

Penelitian yang dilakukan oleh (Rahmat 2021), hasil penelitian dapat disimpulkan bahwa dalam arti luas komunikasi pembangunan meliputi peran dan fungsi komunikasi diantara semua pihak yang terlibat dalam pembangunan, terutama antara masyarakat dan Pemerintah, sejak dari proses perencanaan, pelaksanaan dan evaluasi pembangunan. Dalam arti sempit merupakan segala upaya dan cara serta teknik penyampaian gagasan dan keterampilan-keterampilan pembangunan yang berasal dari pihak yang memprakarsasi pembangunan dan yang dituju yaitu masyarakat luas, dengan harapan tercapainya pemahaman, saling menerima dan partisipasi yang luas dalam pelaksanannya.

Emphathy. Adalah respons afektif dan kognitif yang kompleks pada distres emosional orang lain. Empati termasuk kemampuan untuk merasakan keadaan emosional orang lain, merasa simpatik dan mencoba menyelesaikan masalah, dan mengambil perspektif orang lain kemudian hasil wawancara terhadap informan mereka memberikan jawaban bahwa tanggap petugas selama ini dalam menyelesaikan proses pelayanan publik khususnya tentang informasi, masih kurang optimal, dikarenakan petugas yang kurang disiplin waktu, kurang mengikuti pelatihan pelatihan peningkatan kemampuan seta pengaruh sosial budaya yang kehidupan yang terbawa ke dunia pekerjaan. 
Berdasarkan hasil Penelitian yang telah dilakukan oleh Penggunaan aplikasi Ogan Lopian dalam pelayanan publik merupakan upaya inovasi yang dikembangkan bagi pemerintah setempat dalam memenuhi kebutuhan di bidang kesehatan, keamanan, lowongan pekerjaan, laporan pengaduan masyarakat dsb. Meskipun apa yang dilakukan oleh Kabupaten Purwakarta bukanlah sesuatu hal yang baru di Indonesia. Aplikasi Ogan Lopian yang diluncurkan oleh Diskominfo Pemda Purwakarta masih membutuhkan pematangan dan pemantapan dalam hal sumber daya infrastruktur teknologi, informasi dan komunikasi serta sumber daya manusia pengelola yang dapat menun jang keberhasilan e-government tersebut. Terlepas dari berbagai kekurangannya penerapan e-government lewat aplikasi Ogan Lopian ini dapat dijadikan contoh bagi pemda-pemda lain yang ingin melakukan inovasi dalam penyelenggaraan pelayanan publik di daerahnya.(Dan and Di n.d.)

\section{Simpulan}

Berdasarkan uraian hasil penelitian dan pembahasan, maka penulis dapat menarikan kesimpulan bahwa Pelayanan Informasi Publik pada Dinas Komunikasi dan Informasi Kabupaten Donggala Provinsi Sulawesi Tengah belum berjalan sesuai harapan masyarakat, Hal ini dapat dilihat dari kualitas pelayanan pada proses memberikan pelayanan informasi kepada publik atau masyarakat dikarenakan ke lima aspek tidak dijalankan dengan maksimal yaitu aspek 1) Tangibles; tercermin pada fasilitas fisik, peralatan,personil dan bahan komunikasi. Yaitu masih banyak masalah, dan belum efektif dan optimal dalam pelaksanaan 2) Realibility; kemampuan memenuhi pelayanan yang dijanjikan secara terpercaya, tepat yaitu kurang akurat atau kurangnya terpercaya informasi peleyanan yang diberikan 3) Responsiveness; kemamuan untuk membantu pelanggan dan menyediakan pelayanan yang tepat, yaitu kurangnya kepekaan merespon service informasi sehingga masih banyak yang perlu dibenahi 4) Assurance; pengetahuan dari para pegawai dan kemampuan mereka untuk menerima kepercayaan dan kerahasiaan yaitu, masih kurang efektif dan efisien. 5) Emphathy. Masih kurang tanggapnya petugas dalam proses pelayanan informasi publik.

Untuk terwujudnya pembangunan informasi pelayanan publik yang baik, namun mengingat kondisi Kabupaten Donggala yang memiliki luas area lumayan besar sehingga, tidak representatif untuk pelayanan informasi, jarak dari kecamatan terjauh ke dinas Komunikasi dan Informasi sangatlah memakan waktu yang lama, fasilitas - fasilitas/infrastruktur yang mendukung informasi yang kurang, sumber daya aparatur yang masih belum mengupgrade diri dengan kemajuan zaman atau era revolusi/era globalisasi dimana semua informasi tentang pelayanan publik bisa dapat diperoleh dalam genggaman. Namun masyarakat sampai saat ini masih ada yang belum merasakan. Untuk itu perlu adanya perlakuan khusus atau terobosan (ide-ide cemerlang), atau regulasi/aturan Pemerintah Daerah untuk memutus mata rantai masalah pelayanan infomrasi publik. disini peran pemerintahlah yang sangat ditunggu - tunggu oleh masyarakat karena mereka masih sangat kekuragan infromasi mengenai keterbukaan informasi pelayanan publik.

\section{Referensi}

Ananda, Bobi Rizki, Roni Ekha Putera, and Ria Ariany. 2020. "Inovasi Pelayanan Kesehatan Di Rumah Sakit Umum Daerah Kota Pariaman." Publik (Jurnal Ilmu Administrasi) 8(2):167. doi: 10.31314/pjia.8.2.167-179.2019.

Dan, Komunikasi, and Informatika Di. n.d. "INOVASI PELAYANAN PUBLIK BERBASIS E-GOVERNMENT: STUDI KASUS APLIKASI OGAN LOPIAN DINAS.” 3(1):66-77.

Herlina, Dian. 2020. "Implementasi Kebijakan Keterbukaan Informasi Publik Pada Dinas Kominfo Kota Tasikmalaya." 1(1). 
Hidayah, Dasep Dodi. 2020. "KUALITAS PELAYANAN PUBLIK (Studi Pelayanan Administrasi Kependudukan Di Kecamatan Cipatujah KabupatenTasikmalaya)." Dinamika: Jurnal Ilmiah Ilmu Administrasi Negara 7(1):28-34.

Jaya, Andi Risma. 2019. "Kualitas Pelayanan Masyarakat Di Kecamatan Bontobahari Kabupaten Bulukumba." Publik (Jurnal Ilmu Administrasi) 7(2):123. doi: 10.31314/pjia.7.2.123128.2018 .

Komunikasi, Kementerian. 2020. "Rendahnya Tingkat Perilaku Digital ASN Kementerian Kominfo: Survei Literasi Digital Pada Instansi Pemerintah." 4(July):467-84. doi: 10.25139/jsk.v4i2.2230.

Kusumadinata, Ali Alamsyah, and Maria Fitriah. 2017. "Strategi Komunikasi Pelayanan Publik Melalui Program Pos Pemberdayaan Keluarga." Jurnal ASPIKOM 3(1):225-38.

Maysaroh, Linda. 2018. Kualitas Pelayanan Publik.

Paribrata, Agni Istighfar. 2017. "Volume 1 Implementasi Kebijakan Keterbukaan Informasi Publik Di Jawa Timur Tahun 2016 Tahun-Tahun Undang Komisi Informasi Publik ) Menerapkan Undang Undang Komisi." 1(July):131-62. doi: 10.25139/jsk.v1i2.168.

Puluadji, Yulita K., Abdurrahman Pakaya, and Lucyane Djafar. 2016. "Kualitas Pelayanan Pegawai Di Kantor Camat Dungingi Kota Gorontalo." Ilmu Administrasi 5(2).

Rahmat, Basuki. 2021. "Komunikasi Politik Dprd Dalam Pembangunan Di Daerah.” 2(3):93-100.

Rosmajudi, Arifah. 2020. "Kualitas Pelayanan Keterbukaan Informasi
Publik Pada Dinas Komunikasi Dan Informasi Kota Tasikmalaya." 1(3).

Selviana A. Wahid, Hasbullah, and Dirja N. Jahya. 2018. "Tentang Pengurusan Kartu Tanda Penduduk." Katalogis, Volume 6 Nomor 5 volume 6:181-89.

Siahaan, Chontina, Donal Adrian, Program Studi, Ilmu Komunikasi, Fakultas Ilmu, Ilmu Politik, and Universitas Kristen. 2021. "KEBIJAKAN PEMERINTAH DIMASA PANDEMI ( Studi Kasus Pada Kebijakan Vaksin Covid-19)." 8(2):158-67 